\title{
PENGARUH PAPARAN GENISTEIN TERHADAP MOTORIK ZEBRAFISH (Danio rerio) MELALUI PENGAMATAN EKSPRESI TIROSIN HIDROKSILASE DAN RESEPTOR ESTROGEN
}

\author{
Hanif ${ }^{\star \varpi}$, Habiba Aurora**
}

\begin{abstract}
Abstrak
Motorik dipengaruhi oleh neuron dopaminergik pada otak, yang maturasi fungsi dan morfologi pada masa awal pembentukan dipengaruhi oleh kadar estrogen. Pemberian genistein sebagai fitoestrogen dengan dosis tinggi pada masa awal perkembangan menyebabkan hambatan perkembangan motorik pada zebrafish. Penelitian ini bertujuan membuktikan mekanisme kerja genistein pada neuron dopaminergik, melalui pengamatan ekspresi tirosin hidroksilase (TH), respons taktil, dan tes lokomotor pada embrio zebrafish. Embrio zebrafish dibagi menjadi enam kelompok, yaitu kontrol (DMSO 0,05\%), paparan genistein $5 \mu \mathrm{M}$, paparan genistein $10 \mu \mathrm{M}$, paparan ICl $182.78010 \mu \mathrm{M}$, paparan genistein $5 \mu \mathrm{M}+\mathrm{ICl} 182.78010$ $\mu \mathrm{M}$, paparan genistein $10 \mu \mathrm{M}+\mathrm{ICl} 182.78010 \mu \mathrm{M}$ dan diamati pada 2, 24,48, 72,120 dan 144 hpf (hours post fertilization). Pengamatan ekspresi TH dilakukan pada $48 \mathrm{hpf}$, respons taktil pada $72 \mathrm{hpf}$ dan tes lokomotor pada $144 \mathrm{hpf}$. Hasil penelitian ini menunjukkan bahwa pemberian antagonis estrogen ICl 182.780 memperbaiki ekspresi $\mathrm{TH}$, respon taktil dan kemampuan lokomotor embrio zebrafish secara optimal pada zebrafish yang dipapar genistein $5 \mu \mathrm{M}$.
\end{abstract}

Kata kunci: genistein, motorik, reseptor estrogen, tirosin hidroksilase, zebrafish.

\section{THE EFFECTS OF GENISTEIN EXPOSURE TOWARDS ZEBRAFISH (Danio rerio) MOTOR FUNCTION BY TYROSINE HYDROXYLASE AND ESTROGEN RECEPTORS EXPRESSION OBSERVATION}

\begin{abstract}
The motor is affected by dopaminergic neurons in the brain, whose function and morphology maturation in early formation is determined by estrogen levels. Administration of high-dose genistein as a phytoestrogen in the early developmental stages causes inhibition of motor development in zebrafish. This study aims to prove the mechanism of action of genistein in dopaminergic neurons, through observation of tyrosine hydroxylase $(\mathrm{TH})$ expression, tactile response, and locomotor tests on zebrafish embryos. Zebrafish embryos are divided into six groups, namely control (0.05\% DMSO), $5 \mu \mathrm{M}$ genistein exposure, $10 \mu \mathrm{M}$ genistein exposure, $182,780 \mathrm{ICl}$ 182,780, $\mu \mathrm{M}$ genistein exposure, $5 \mu \mathrm{M}$ genistein $+182,78010 \mu \mathrm{M}$ genistein exposure, $182,780 \mathrm{ICl}$ exposure $10 \mu \mathrm{M}$ and observed at 2, 24.48, 72.120 and $144 \mathrm{hpf}$ (hours postfertilization). Observations of TH expression were carried out at 48hpf, the tactile response at $72 \mathrm{hpf}$, and locomotor tests at $144 \mathrm{hpf}$. The results of this study indicate that administration of the ICl 182,780 estrogen antagonist improves TH expression, tactile response, and optimal locomotor zebrafish ability in zebrafish exposed to $5 \mu \mathrm{M}$ genistein, while higher doses of genistein exposure showed decreased performance.
\end{abstract}

Keywords: estrogen receptor, genistein, motor, tyrosine hydroxylase, zebrafish.

\footnotetext{
^ Departemen Anestesiologi dan Terapi Intensif, Fakultas Kedokteran, Universitas Brawijaya
}

* Departemen Radiologi, Fakultas Kedokteran, Universitas Brawijaya

\footnotetext{
E-mail: dr.hanif@ub.ac.id
} 


\section{Pendahuluan}

Sistem endokrin memainkan peran penting dalam semua vertebrata dan mengatur fungsi biologis penting sebagai metabolisme, pengembangan, reproduksi, dan perilaku. Namun, paparan endocrine disrupting chemicals (EDCs) semakin banyak ditemukan. ${ }^{1}$ Sebagian besar EDCs bersifat lipofilik, dapat menembus membran sel, dan bekerja dalam sel melalui reseptor intraselular. Suatu EDC dapat berikatan pada satu atau lebih reseptor hormon dan berperan sebagai agonis, antagonis, maupun keduanya. Beberapa EDC dapat berpengaruh terhadap metabolisme dan degradasi hormon sehingga mengubah kemampuan kerja hormon dalam suatu organisme.1,2

Akhir-akhir ini, banyak dilakukan penelitian terkait EDCs, terutama terkait perannya melalui jaras reseptor estrogen. EDCs dapat bersifat antiestrogenik, androgenik, antiandrogenik, pengacau tiroid, serta bekerja pada reseptor hormon membran. EDCs banyak ditemukan baik dalam bentuk sintetis maupun senyawa alami yang berdampak pada kesehatan dan lingkungan. Salah satu bentuk senyawa alami EDCs adalah genistein. ${ }^{1}$ Genistein $\left(4^{\prime}, 5,7-\right.$ trihydroxyisoflavon) merupakan suatu isoflavon yang berasal dari kedelai dan turunan kedelai yang dikategorikan sebagai fitoestrogen lemah. Genistein hingga saat ini merupakan senyawa fitoestrogen yang paling banyak diteliti, dan ditemukan bahwa senyawa ini memiliki aktivitas estrogenik dan antiestrogenik pada manusia, rodensia, dan ikan. 3,4

Pada praktik klinis, genistein memiliki peran yang penting dalam mencegah atau sebagai terapi kanker, osteoporosis, premenopause, menurunkan risiko kanker tiroid, kanker kolorektal, kerusakan ginjal, dan penyakit jantung. Walaupun penelitian terhadap genistein menunjukkan bahwa senyawa ini merupakan kompetitor yang sangat kuat bagi estradiol terhadap reseptor estrogen (ER). ${ }^{4}$ Genistein merupakan fitoestrogen dengan kemampuan transaktifasi yang paling tinggi terhadap reseptor estrogen, walaupun afinitasnya lebih rendah dari coumestrol, genistein memiliki struktur menyerupai estrogen dan dapat berikatan dengan reseptor estrogen (ER) a maupun $\beta$. Senyawa ini menunjukkan afinitas yang tinggi terhadap ER $\beta$ hingga 9 kali lipat dibandingkan dengan ERa pada manusia. Dari struktur ikatan genistein dengan estrorgen reseptor, genistein membentuk ikatan sebagai partial agonis dari estrogen. 3,4

Zebrafish (Danio rerio) merupakan salah satu spesies yang dikenalkan oleh Ankley dan Johnson (2004) sebagai model vertebrata yang dapat digunakan untuk mengidentifikasi dan menilai efek dari endocrine disrupting chemicals (EDCs) karena embriogenesis yang cepat dan memiliki larva yang transparan sehingga mudah untuk dievaluasi serta srtuktur umum dan domain fungsi dari reseptor estrogen serupa dengan manusia. ${ }^{3-6}$

Paparan genistein dalam dosis tinggi dapat menimbulkan efek teratogenik pada embrio zebrafish. Penelitian terdahulu menunjukkan bahwa paparan genistein pada embrio zebrafish meningkatan ekspresi mRNA aromatase- $B$, serta menurunan ekspresi tyrosine hydroxylase (TH) pada neuron dopaminergik dari larva zebrafish. Penelitian terdahulu menunjukkan kemungkinan genistein bekerja melalui reseptor estrogen dalam mempengaruhi neuron dopaminergik. 4,7

Terdapat berbagai macam modulator reseptor estrogen agonis, antagonis, dan selektif yang telah digunakan untuk memahami lebih baik peran dari reseptor spesifik dalam berbagai proses fisiologis. Antiestrogen tipe I seperti ICl 182,780 merupakan suatu antagonis murni nonselektif yang bekerja dengan menghambat seluruh aktivitas estrogen pada semua jaringan. 
Penelitian terdahulu menunjukkan bahwa antagonis reseptor estrogen $\mathrm{ICl}$ 182,780 mampu menghambat aktivasi transkripsi yang diinduksi $17 \beta$-estradiol (E2) pada zebrafish dalam semua isoform. 6,8

Penelitian ini bertujuan untuk mengetahui mekanisme kerja genistein dan kombinasinya dengan ICl 182,780 terhadap fungsi motorik dengan menggunakan zebrafish sebagai model.

\section{Bahan dan Metode}

Pemeliharaan Ikan dan Pengambilan Telur

Zebrafish dewasa dipelihara pada akuarium $60 \mathrm{~L}$, dengan suhu air $25-30{ }^{\circ} \mathrm{C}$. Siklus periode terang 14 jam dan periode gelap 10 jam. Pengambilan telur dilakukan 15 -25 menit setelah periode terang dimulai. ${ }^{7}$

\section{Kultur Embrio}

Telur yang terfertilisasi diletakkan pada culture plate dengan 6 wells $(30$ embrio/ $/ 8 \mathrm{~mL}$ embrio medium/plate), dan diinkubasi pada suhu $28 \pm 0,5{ }^{\circ} \mathrm{C}$. Paparan dimulai 2 jam setelah telur terfertilisasi. Kemudian, dibentuk enam kelompok, yaitu kontrol (DMSO 0,05\%), paparan genistein $5 \mu \mathrm{M}$, paparan genistein $10 \mu \mathrm{M}$, paparan ICI $182.78010 \mu \mathrm{M}$, paparan genistein $5 \mu \mathrm{M}+\mathrm{ICl} 182.78010 \mu \mathrm{M}$, paparan genistein $10 \mu \mathrm{M}+\mathrm{ICl} 182.78010 \mu \mathrm{M}$. Pengamatan dilakukan pada 2, 24,48, 72,120 dan $144 \mathrm{hpf}$.

\section{Pengamatan Motorik}

Pengamatan motorik dievaluasi melalui defek morfologi, respons taktil dan tes aktifitas lokomotor. Defek morfologi dievaluasi dengan membandingkan secara visual morfologi larva yang terpapar genistein dan genistein $+\mathrm{ICl}$ dengan kontrol yang dinilai pada 72 hpf. Respons taktil dinilai pada embrio berumur 48 dan 72 hpf, dengan melakukan sentuhan pada ekor embrio yang diam menggunakan jarum. Dihitung jumlah embrio yang berenang melewati garis setelah distimulasi. Tes aktifitas lokomotor dievaluasi pada 144 hpf menggunakan culture plate dengan 12 wells yang masing-masing dibagi menjadi empat bagian. Pengamatan dilakukan dengan merekam aktifitas zebrafish selama 1 menit, dan dihitung jumlah garis yang dilewati oleh larva zebrafish.

\section{Pengamatan Ekspresi Tirosin Hidroksilase}

Embrio dikeluarkan dari cangkang pada $48 \mathrm{hpf}$, difiksasi dalam paraformaldehyde $4 \%$ pada suhu $4{ }^{\circ} \mathrm{C}$, kemudian disimpan dalam methanol $100 \%$ pada $-20{ }^{\circ} \mathrm{C}$. Dilanjutkan dengan tahapan permeabilisasi embrio menggunakan aquades dan aceton selama 8 menit. Blocking menggunakan $1 \%$ normal goat serum dan $3 \%$ bovine serum albumin. Antibodi primer TH monoklonal (immunostar \#22941) digunakan dalam 1:1000 selama 24 jam dan antibodi sekunder Alexa Fluor 488 Invitrogen A11001 1:200 selama 2 jam. Embrio difiksasi pada agarose gel 1\% dan diamati dengan mikroskop fluoresens Olympus di Laboratorium Biologi, FMIPA Universitas Brawijaya, kemudian dianalisis dengan Image-J software. Dalam menggunakan Image-J software, hasil gambar fluoresens yang dievaluasi dikalibrasi ke dalam ukuran pixel, kemudian dilakukan perhitungan rata-rata dari hasil masingmasing kelompok perlakuan.

\section{Hasil}

Pada penelitian ini embrio zebrafish dibedakan berdasarkan enam kelompok yaitu kontrol (DMSO 0,05\%), paparan genistein 5 $\mu \mathrm{M}$, paparan genistein $10 \mu \mathrm{M}$, paparan $\mathrm{ICl}$ $182.78010 \mu \mathrm{M}$, paparan genistein $5 \mu \mathrm{M}+\mathrm{ICl}$ $182.78010 \mu \mathrm{M}$, paparan genistein $10 \mu \mathrm{M}+$ ICl $182.780 \quad 10 \mu \mathrm{M}$ untuk mengamati pengaruh genistein dan kombinasinya dengan ICI 182.780 terhadap terjadinya defek morfologi dan aktivitas motorik melalui penilaian pada respons taktil dan aktivitas lokomotor. 
Senyawa ICl 182.780 adalah blocker ER -kompetetif inhibitor, yang berfungsi untuk mengurangi efek E2 endogen. Kemudian, pada $72 \mathrm{hpf}$ dilakukan pengamatan terhadap embrio. Embrio yang dipapar genistein sejak $2 \mathrm{hpf}$ menunjukkan hambatan pertumbuhan dibanding kelompok kontrol (Gambar 1), terlihat defek morfologi berupa pembesaran perikardium, tulang belakang tidak terbentuk sempurna, dan dapat ditemukan embrio yang tidak menetas. Defek morfologi pada embrio zebrafish mulai teramati pada paparan genestein $5 \mu \mathrm{M}$ dan pada dosis $10 \mu \mathrm{M}$

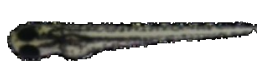

A seluruh embrio mengalami defek morfologis (Gambar 2).

Pada evaluasi respons taktil didapatkan adanya penurunan respons terhadap stimulasi taktil pada embrio yang diam yang dipapar genistein, dan ditemukan peningkatan respons taktil pada kelompok yang diberi perlakuan kombinasi genistein + ICI 182.780. Penurunan respons taktil terbesar didapatkan pada kelompok paparan genistein $10 \mu \mathrm{M}(14 \%$ dan $0 \%$ respons taktil pada 48 hpf dan 72 hpf, secara berurutan) (Tabel 1).

\section{Gambar 1. Embrio zebrafish pada $72 \mathrm{hpf}$.}

Keterangan: (A) Embrio zebrafish yang tidak dipapar genistein, (B) Embrio yang dipapar genistein sejak 2 hpf dan dikeluarkan dari cangkang secara manual, menunjukkan adanya defek morfologis.

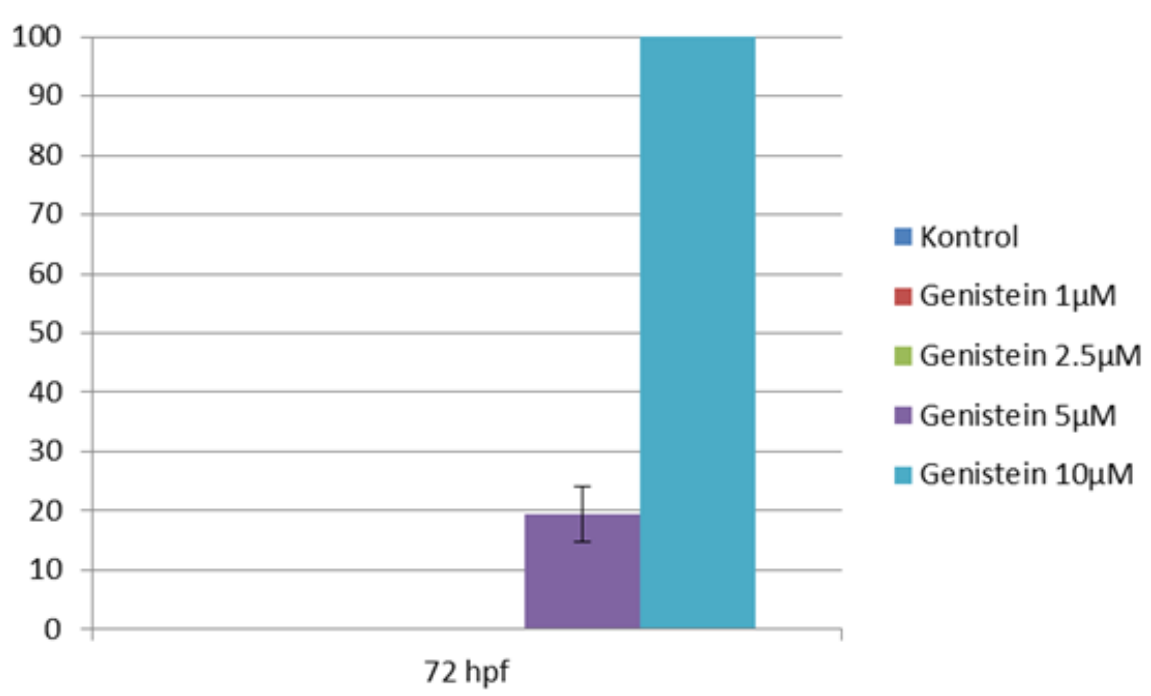

Gambar 2. Temuan defek morfologi berdasarkan dosis paparan genistein.

Keterangan: Paparan genistein pada embrio zebrafish dengan dosis $5 \mu \mathrm{M}$ mulai menunjukkan terjadinya defek morfologis, sementara pada dosis $10 \mu \mathrm{M}$ seluruh embrio mengalami defek morfologis. 
Hasil pengukuran aktivitas lokomotor pada 144 hpf menunjukkan terdapat penurunan aktivitas lokomotor pada kelompok yang diberi paparan genistein baik $5 \mu \mathrm{M}$ maupun $10 \mu \mathrm{M}$ dibandingkan kelompok kontrol. Kemudian, penilaian pada kelompok paparan genistein yang dikombinasi dengan ICl 182.780 menunjukkan peningkatan aktivitas lokomotor yang signifikan $(p<0,05)$ dibandingkan kelompok yang tidak dikombinasi dengan ICI (Tabel 2).
Sementara, pada Gambar 3 diketahui hasil pengamatan ekspresi TH dari embrio berusia $48 \mathrm{hpf}$ didapatkan penurunan ekspresi TH pada kelompok yang terpapar genistein dibandingkan kelompok kontrol $(p<$ $0,05)$. Sementara pada kelompok kombinasi genistein dan $\mathrm{ICl}$ menunjukkan ekspresi $\mathrm{TH}$ yang lebih tinggi dibandingkan pada kelompok genistein saja (Tabel 3).

Tabel 1. Rata-rata jumlah embrio zebrafish dengan respons taktil pasca stimulasi

\begin{tabular}{lccc}
\hline \multicolumn{1}{c}{ Kelompok } & $(48 \mathrm{hpf})+\mathrm{SD}$ & $(72 \mathrm{hpf}+\mathrm{SD}$ & Nilai p \\
\hline Kontrol & $43,67+1,20$ & $44,67+0,67$ & \\
Genistein $5 \mu \mathrm{M}$ & $40,33+2,03$ & $43+1,00$ & \\
Genistein $10 \mu \mathrm{M}$ & $7+3,79$ & 0 & \\
ICl 182.780 & $39,67+0,67$ & $42+1,15$ & 0,000 \\
ICI $182.780+$ Genistein $5 \mu \mathrm{M}$ & $39,67+0,33$ & $41,3+0,33$ & \\
ICl $182.780+$ Genistein $10 \mu \mathrm{M}$ & $34,33+1,45$ & $33,67+1,76$ & \\
\hline
\end{tabular}

Tabel 2. Rata-rata hasil pengukuran aktivitas lokomotor embrio zebrafish (144 hpf)

\begin{tabular}{lcc}
\hline \multicolumn{1}{c}{ Kelompok } & Aktivitas lokomotor+SD & Nilai $p$ \\
\hline Kontrol & $10,18+1,10$ & \\
Genistein $5 \mu \mathrm{M}$ & $6,5+0,89$ & \\
Genistein $10 \mu \mathrm{M}$ & 0 & 0,000 \\
$\mathrm{ICl} 182.780$ & $9,58+0,87$ & \\
$\mathrm{ICl} 182.780+$ Genistein $5 \mu \mathrm{M}$ & $8,61+1,43$ & \\
$\mathrm{ICI} 182.780+$ Genistein $10 \mu \mathrm{M}$ & $4,26+0,79$ & \\
\hline
\end{tabular}

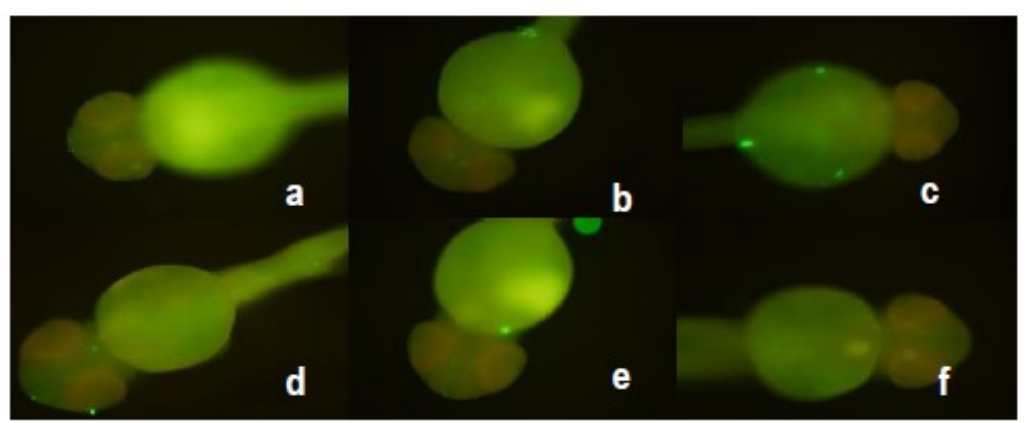

Gambar 3. Ekspresi tirosin hidroksilase pada embrio zebrafish berusia $48 \mathrm{hpf}$ pasca perlakuan. Keterangan: a. kontrol positif; b. paparan genistein $5 \mu \mathrm{M}$; c. paparan genistein $10 \mu \mathrm{M}$; d. paparan $\mathrm{ICl}$ $182.78010 \mu \mathrm{M}$; e. paparan ICI $182.78010 \mu \mathrm{M}+$ genistein $5 \mu \mathrm{M}$; f. paparan ICI 182.78010 $\mu \mathrm{M}+$ genistein $10 \mu \mathrm{M}$. 
Tabel 3. Rata-rata ekspresi tirosin hidroksilase pada embrio zebrafish $48 \mathrm{hpf}$

\begin{tabular}{lcc}
\hline \multicolumn{1}{c}{ Kelompok } & Ekspresi TH + SD & Nilai p \\
\hline Kontrol & $58,99+0,32$ & \\
Genistein $5 \mu \mathrm{M}$ & $48,15+0,57$ & \\
Genistein $10 \mu \mathrm{M}$ & $44,31+3,11$ & 0,000 \\
ICl 182.780 & $56,18+1,61$ & \\
ICl $182.780+$ Genistein $5 \mu \mathrm{M}$ & $53,61+1,09$ & \\
ICl $182.780+$ Genistein $10 \mu \mathrm{M}$ & $49,69+1,30$ & \\
\hline
\end{tabular}

\section{Pembahasan}

Hasil pengamatan didapatkan hambatan pertumbuhan pada kelompok embrio yang dipapar genistein mulai dosis $5 \mu \mathrm{M}$ yang terlihat sebagai defek morfologi dibandingkan dengan kelompok kontrol. Hasil tersebut memperkuat dugaan tentang paparan genistein pada dosis tertentu yang bersifat teratogenik pada embrio zebrafish. Senyawa ICl 182.780 merupakan suatu antiestrogen murni yang bekerja dengan mengikat reseptor estrogen, baik ERa maupun ERß, bersifat inhibitor kompetitif bagi senyawa estrogen dan turunannya. ${ }^{17} \mathrm{Hal}$ ini kemudian mengakibatkan penurunan aktivitas senyawa estrogen, baik estrogen endogen maupun eksogen seperti genistein.

Penelitian terdahulu menemukan bahwa toksisitas genistein terhadap perkembangan embrio zebrafish bergantung pada konsentrasi dan waktu paparan, pada dosis genistein $10 \mathrm{mg} / \mathrm{L}$ merupakan dosis letal untuk embrio dan paparan genistein $5 \mathrm{mg} / \mathrm{L}$ menyebabkan penurunan dalam kelangsungan hidup dalam 24 hpf diikuti oleh kematian 100\% embrio pada 72 hpf. ${ }^{9}$

Bukti lain menunjukkan bahwa lebih dari $60 \%$ embrio zebrafish yang diberi paparan genistein $6,75 \mathrm{mg} / \mathrm{L}$ pada $24 \mathrm{hpf}$ hanya dapat bertahan hidup hingga $84 \mathrm{hpf}$. Sementara itu, $90 \%$ embrio yang diberi paparan genistein 4,7 mg/L mampu bertahan hidup hingga 96 hpf dan tidak ditemukan efek paparan genistein terhadap embrio zebrafish pada dosis $\leq 2,7 \mathrm{mg} / \mathrm{L} .{ }^{10}$
Terjadi penurunan sebesar $43 \%, 12 \%$ dan $0 \%$ terhadap keberhasilan perkembangan embrio zebrafish pada paparan genistein dengan konsentrasi 6,75, 13,5 dan $27 \mathrm{mg} / \mathrm{L}$. Gangguan pertumbuhan maupun diferensiasi sel dapat terjadi akibat keterlibatan genistein dalam regulasi siklus sel, antiangiogenesis, serta aktivitas antioksidan. ${ }^{11}$

Genistein memiliki kemampuan untuk menyebabkan apoptosis di otak dan perubahan ukuran kepala dan warna kulit. Pada embrio zebrafish dapat terjadi defek morfologis atau perilaku. Perubahan morfologi lain yang diamati pada larva yang diberi perlakuan genistein adalah perubahan morfologi jantung dan penurunan detak jantung. ${ }^{7}$ Perubahan morfologi yang disebabkan oleh genistein pada embrio zebrafish termasuk penurunan tingkat pigmentasi tubuh. Efek genistein pada suplai nutrisi berkurang ke organ yang sedang berkembang, seperti kulit. Ini menyebabkan juga adanya pembesaran ekstensi kuning telur dan pembentukan pembuluh darah. ${ }^{12}$ Ciri lain yang diberi perlakuan genistein adalah adanya malformasi ekor. Konsentrasi genistein yang menyebabkan efek ini $(\geq 2,5$ $\mathrm{mg} / \mathrm{L}$ ) juga menyebabkan malformasi sumbu tubuh. 9 Hal ini dapat menjelaskan alasan mengapa pada penelitian ini embrio zebrafish yang dipapar genistein mengalami gangguan respons taktil dan aktivitas lokomotor seperti yang diamati pada penelitian ini, dan pemberian $\mathrm{ICl} 182.780$ sebagai antagonis murni dari reseptor estrogen memberikan perbaikan hasil pengamatan. 
Keterlibatan reseptor estrogen dalam sinyal estrogen pada embrio zebrafish menunjukkan bahwa jalur reseptor estrogen tergantung oleh banyak faktor yang mungkin juga dipengaruhi oleh senyawa estrogenik. Dalam konteks ini, neuron gonadotropinreleasing-hormone $(\mathrm{GnRH})$ penting sebagai target hormon steroid dan menurut penelitian terbaru menyebutkan ontogeni neuron $(\mathrm{G} n \mathrm{RH})$ dapat dimodifikasi dalam ketergantungan reseptor estrogen setelah paparan EE2. Oleh karena neuron $\mathrm{GnRH}$ juga pengatur penting perkembangan gonad dan diferensiasi seksual, maka disregulasi neuron $\mathrm{GnRH}$ dapat menyebabkan efek reproduktif yang berat pada zebrafish dewasa. ${ }^{13}$

Secara khusus di zebrafish, jaras estrogenik dan dopaminergik terkait erat pada vertebrata, melalui sumbu hipotalamushipofisis-gonad (HPG). Dopaminergik neuron diaktivasi oleh peningkatan konsentrasi E2, yang selanjutnya menghambat pelepasan hormon pelepas gonadotropin $(\mathrm{GnRH})$, dan hormon gonadotropin (GtH), keduanya disintesis oleh hipotalamus dan hipofisis. Dopamin disintesis dari tirosin oleh tirosin hidroksilase $(\mathrm{TH})$ yang merupakan enzim langkah pembatas laju dalam biosintesis DA. Pensinyalan estrogenik terutama terjadi melalui aktivasi ER.14,15

Selain memiliki efek estrogenik, genistein juga memiliki efek antioksidan dan memiliki kemampuan untuk menghambat tirosin hidroksilase yang berakibat pada penurunan aktivitas motorik. Namun, pemberian kombinasi ICI 182.780 berlawanan dengan efek yang ditimbulkan genistein, yang mengindikasikan bahwa aktivitas genistein berkaitan dengan reseptor estrogen. ${ }^{16}$

Bukti penelitian di atas mendukung temuan penelitian ini bahwa paparan genistein memiliki efek terhadap terjadinya penurunan ekspresi $\mathrm{TH}$ dan $\mathrm{ICl} 182.780$ berperan sebagai antagonis dari efek genistein.

\section{Kesimpulan}

Kesimpulan penelitian ini adalah semakin tinggi dosis paparan genistein maka semakin besar gangguan yang ditimbulkan terkait aktivitas motorik zebrafish, baik akibat terjadinya defek morfologis maupun penurunan aktivitas neuron dopaminergik dari zebrafish. Selain itu, juga dibuktikan bahwa $\mathrm{ICl} 182.780$ sebagai antagonis murni reseptor estrogen nonselektif dapat mengurangi gangguan yang timbul akibat paparan genistein.

\section{Daftar Pustaka}

1. Gore AC, Krishnan K, Reilly MP. Endocrine-Disrupting Chemicals: Effects on Neuroendocrine Systems and the Neurobiology of Social Behavior. Hormones and Behaviour. 2019; 111:7-22. DOI: 10.1016/j.yhbeh.2018.11.006.

2. Balaguer $P$, Delfosse $V$, Grimaldi $M$, Bourguet $W$, Structural and Functional Evidences for the Interactions between Nuclear Hormone Receptors and Endocrine Disruptors at Low Doses. Comptes Rendus Biologies. 2017; 340:412 -420 .

3. Schiller V, Wichmann A, Kriehuber R, Muth-Kohne E, Giesy JP, Hecker M, Fenske M. Studying the Effects of Genistein on Gene Expression of Fish Embryos as an Alternative Testing Approach for Endocrine Disruption. Comparative Biochemistry and Physiology Part C: Toxicology and Pharmacology. 2013; 157:41-53.

4. Licata P, Tardugno R, Pergolizzi S, Capillo G, Aragona M, Colombo A, Gervasi T, Pellizzeri V, Cicero N, Calo M. In Vivo Effects of PCB-126 and Genistein on Vitellogenin Expression in Zebrafish. Natural Product Research. 2019; 33 $(17): 2507-2514$. D O I: 10.1080/14786419.2018.1455048. 
5. Zielinska KA., The Influence of Environmental Estrogens on Early-Life Stage Zebrafish Development. Doctoral Thesis. Galway Ireland: National University of Ireland. 2013. Retrieved from http://hdl.handle.net/10379/3569.

6. Notch EG \& Mayer GD. Efficacy of Pharmacological Estrogen Receptor Antagonists in Blocking Activation of Zebrafish Estrogen Receptors. General and Comparative Endocrinology. 2011; 173:183-189.

7. Aurora H, Lyrawati D. Efek Waktu Paparan Genistein terhadap Pembentukan Jantung Embrio Zebrafish. Jurnal Kedokteran Brawijaya. 2014; 28 (1):22-25.

8. Lam SH, Lee SGP, Lin CY, Thomsen JS, Fu PY, Murthy KRK, Li H, Govindarajan $K R$, Nick LCH, Bourque G, Gong Z, Lufkin T, Liu ET, Mathavan S. Molecular Conservation of Estrogen-Response Associated with Cell Cycle Regulation, Hormonal Carcinogenesis and Cancer in Zebrafish and Human Cancer Cell Lines. BMC Medical Genomics. 2011; 4(41):115.

9. Sarasquete $C$, Úbeda-Manzanaro $M$ \& Ortiz-Delgado JB. Effects of the Isoflavone Genistein in Early Life Stages of the Senegalesesole, Solea senegalensis: Role of the Surviving and Proliferation Versus Apoptosis Pathways. BMC Vet Res. 2018; 14:16. DOI: doi.org/10.1186/s12917-018-1333-3.

10. Sassi-Messai S, Gibert $Y$, Bernard L, Nishio S, Ferri Lagneau KF, Molina J, Andersson-Lendahl $M$, Benoit $G$, Balaguer $P, \&$ Laudet $V$. The Phytoestrogen Genistein Affects Zebrafish Development through Two Different Pathways. PloS One. 2009; 4 (3):e4935. DOI: doi.org/10.1371/ journal.pone.0004935.

11. Kim DJ, Seok SH, Baek MW, Lee HY, Na YR, Park SH, Lee HK, Dutta NK,
Kawakami K, Park JH. Developmental Toxicity and Brain Aromatase Induction by High Genistein Concentrations in Zebrafish Embryos. Toxicology Mechanisms and Methods. 2009; 19 (3):251256, DOI: 10.1080/153765108025 3330.

12. Bakkiyanathan $A$, Joseph $A M$, Tharani $L$, Malathi R. Genistein, the Phytoestrogen Induces Heart-and-Soul (has) Phenotypes in Zebrafish Embryo. Journal of Developmental Biology and Tissue Engineering. 2010; 2(2):18-22.

13. Brown AC, Stevenson LM, Leonard HM, Nieves-Puigdoller K, Clotfelter ED. Phytoestrogens $\beta$-Sitosterol and Genistein have Limited Effects on Reproductive Endpoints in a Female Fish, Betta Splendens. Biomed Res Int. 2014; 2014:681396.

14. Vosges M, Kah O, Hinfray N, Chadili E, Le Page $Y$, Combarnous $Y$, Porcher JM, Brion F. 17a-Ethinylestradiol and Nonylphenol Affect the Development of Forebrain GnRH Neurons through an Estrogen Receptor-Dependent Pathway. Reprod. Toxicol. 2012; 33 (2):198-204.

15. Bertotto LB, Dasgupta S, Vliet S, Dudley S, Gan J, Voiz DC, Schlenk D. Evaluation of the Estrogen Receptor Alpha as a Possible Target of Bifenthrin Effects in the Estrogenic and Dopaminergic Signaling Pathways in Zebrafish Embryos. Sci Total Environ. 2019; 651 (2): 2424-2431.

16. Kyuhou S. Preventive Effects of Genistein on Motor Dysfunction Following 6Hydroxydopamine Injection in Ovariectomized Rats. Neuroscience Letters. 2008; 448:10-14.

17. Song Z, Yang H, Peckham EM, Becker JB. Estradiol-Induced Potentiation of Dopamine Release in Dorsal Striatum Following Amphetamine Administration Requires Estradiol Receptors and mGlu5. ENeuro. 2019; 6(1): e0446-18.2019 1-8. 